\title{
The position of the hyaline papilla and the genus concept of Cheilolejeunea (Spruce) Schiffn. (Lejeuneaceae)
}

\author{
CID JOSÉ PASSOS BASTOS ${ }^{1}$
}

(received: April 04, 2009; accepted: March 11, 2010)

\begin{abstract}
The position of the hyaline papilla and the genus concept of Cheilolejeunea (Spruce) Schiffn. (Lejeuneaceae)). In this paper, the genus concept of Cheilolejeunea is discussed and revalued based upon the concept of the real position of the hyaline papilla, as well as upon the definition of apical tooth of the lobule in the genus.
\end{abstract}

Key words - apical tooth, Cheilolejeunea, hyaline papilla, Lejeuneaceae, taxonomy

RESUMO - (A posição da papila hialina e o conceito do gênero Cheilolejeunea (Spruce) Schiffn. (Lejeuneaceae)). Neste trabalho, o conceito do gênero Cheilolejeunea é discutido e reavaliado à luz do real conceito da posição da papila hialina, bem como da definição de dente apical do lóbulo no gênero.

Palavras-chave - Cheilolejeunea, dente apical, Lejeuneaceae, papila hialina, taxonomia

The genus Cheilolejeunea (Spruce) Schiffn. has been defined by the position of hyaline papilla, which is distal to the apical tooth (second tooth), large and segmented oil bodies of Calypogeia-type, small and slightly or strongly mammillose cells, and rosettes on the surface of spores (Zhu \& Reiner-Drehwald 2004). However, as pointed out by He (1996), the position of hyaline papilla shows less taxonomic importance than the lobule's structure in Lejeuneaceae. Therefore, the genus concept of Cheilolejeunea needs to be revalued. The aim of this paper is to discuss the genus concept of Cheilolejeunea considering the real position of the hyaline papilla and the concept of the apical tooth in the genus. The taxonomic discussion was based on specialized literature, such as Mizutani (1961), Schuster (1980), He (1996), Zhu \& So (1999), Zhu \& ReinerDrehwald (2004) and Zhu (2006).

The circumscription of the genus Cheilolejeunea is still controversial. Oil bodies are not exclusively of the Calypogeia-type, (some species have Jungermanniatypes); some species present strongly mammillose, papillose cells or slightly mammillose cells. However, the position of the hyaline papilla related to the lobule structure seems to be more critical.

According to $\mathrm{He}$ (1996), the lobule tooth in Lejeuneaceae has been a significant character in the

1. Universidade Federal da Bahia, Instituto de Biologia, Departamento de Botânica, Laboratório de Taxonomia de Briófitas, câmpus de Ondina, 40170-280 Salvador, BA, Brasil. cjpbasto@ufba.br taxonomy of the family. In Ptychanthoideae, the free margin bears 1-11 teeth, with the first or apical tooth situated near the lobule apex. In Lejeuneoideae, all genera of the tribe Brachiolejeuneeae (except Neurolejeunea) share position of the lobule teeth with the Ptychanthoideae. In the remaining Lejeuneoideae, the free margin bears one or two lobule teeth, which are separated or rarely lightly associated (e.g., Trachylejeunea) (He 1996). In some taxa, however, one or both lobule teeth can be reduced.

Most of the genera of Lejeuneaceae present lobules with a single 1-celled, well developed tooth, which is usually considered the first tooth; in this case, the second tooth is reduced and usually inconspicuous. In Cheilolejeunea laevicalyx (I. B. Jack \& Steph.) Grolle, the first tooth is usually the most developed one (Zhu 2006). Nevertheless, in several species of Cheilolejeunea and Leucolejeunea A. Evans, as demonstrated by Mizutani (1961), the second tooth is well developed while the first tooth is reduced, obsolete or inconspicuous. The same can be observed in other related genera, such as Aureolejeunea R. M. Schust., Omphalanthus Lindenb. and Oryzolejeunea (R. M. Schust.) R. M. Schust.

He (1996) recognized two types of hyaline papilla position in Lejeuneaceae: hyaline papilla on the free margin, proximal to the first tooth (present in most of the taxa), and hyaline papilla on the inner side of the lobule, near the proximal base of the first tooth. Thus, the hyaline papilla is always proximal to the first tooth, when present. Upon this consideration, characters that 
limit Cheilolejeunea, as well as the related genera of the Aureolejeunea-Omphalanthus clade (Groth-Malloneck et al. 2004, tribe Cheilolejeuneeae sense Schuster 2001) must be revalued. Therefore, one the most important characters that circumscribes Cheilolejeunea is not the hyaline papilla position, but the presence of a well developed second tooth, since hyaline papilla is always distal to the second tooth and proximal to the first tooth. Nevertheless, in Cheilolejeunea, the hyaline papilla is always positioned exactly at the distal base of second tooth.

Recently, Zhu (2006) provided descriptions and illustrations for Cheilolejeunea krakakammae (Lindenb.) R. M. Schust. and Cheilolejeunea laevicalyx (J. B. Jack \& Steph.) Grolle. Concerning to Cheilolejeunea laevicalyx, the hyaline papilla is situated at the proximal base of the first tooth, which is poorly developed, being the second tooth smaller. Its lobule resembles the one of Lejeunea boliviensis (Steph.) R. L. Zhu \& E. Reiner (see Zhu \& Reiner-Drehwald 2004).

The genus Cheilolejeunea may be better delimited by the following set of characters: a) second lobule tooth well developed, first lobule tooth obsolete or not developed; b) oil-bodies of the Calypogeia-type or Jungermannia-type; c) strongly or slightly mammillose cells, or strongly papillose cells on the dorsal leaf surface lobe; d) small lobule cells; e) lejeuneoid or pycnolejeuneoid innovations; f) rosettes on the spore surface.

Therefore, a revision of the genus Cheilolejeunea and its relatives (tribe Cheilolejeuneeae, sense Schuster 2001) is urgently needed.
Acknowledgements - The author is grateful to anonymous referee for their commentaries.

\section{References}

GROTH-MALONECK, M., HEINRICHS, J., SCHNEIDER, H. \& GRADSTEIN, S.R. 2004. Phylogenetic relationships in the Lejeuneaceae (Hepaticae) inferred using ITS sequences of nuclear ribosomal DNA. Organisms, Diversity \& Evolution 4:51-57.

HE, X.-L. 1996. On the taxonomic significance of lobule characters in the Lejeuneaceae (Hepaticae). Annales Botanici Fennici 33:311-316.

MIZUTANI, M. 1961. A revision of Japanese Lejeuneaceae. Journal of the Hattori Botanica Laboratory 24:155302.

SCHUSTER, R.M. 1980. Hepaticae and Anthocerotae of North America east Handredht Meridian. Columbia University Press, New York.

SCHUSTER, R.M. 2001. Studies on Lejeuneaceae, IV. On the circumscription and subdivision of the subfamily Lejeuneoideae. Journal of the Hattori Botanical Laboratory 91:137-172.

ZHU,R.-L.2006. Taxonomy and distribution of Cheilolejeunea krakakammae (Lejeuneaceae, Jungermanniopsida, Marchantiophyta), with a description and illustration of Cheilolejeunea laevicalyx from Bolivia, Colombia and Ecuador. Nova Hedwigia 83:187-198.

ZHU, R.-L. \& REINER-DREHWALD, M.E. 2004. Lejeunea bolviensis, a remarkable species with bizarre underlaeves and eplicate perianths. The Bryologist 107:237-241.

ZHU, R.-L. \& SO, M.L. 1999. Addition of Lejeuneaceae taxa to the hepatica flora of Yunnan, China. Annales Botanici Fennici 36:219-229. 